\title{
Kinerja Bidang Pengelolaan Pasar Dalam Pemungutan Retribusi Pasar Pada Dinas Koperasi, UMKM, Perdagangan dan Perindustrian Kabupaten Subang
}

\author{
Luki Natika1 \\ Fakultas Ilmu Administrasi Universitas Subang \\ lukinatika85@gmail.com \\ Iwan Henri Kusnadi ${ }^{2}$ \\ Fakultas Ilmu Administrasi Universitas Subang \\ iwanhenri01@gmail.com
}

Sri Dinarwati ${ }^{3}$

Fakultas Ilm Administrasi Universitas Subang sridinarwati94@gmail.com

Ade Suparman ${ }^{4}$

FakultasIlmu Administrasi Universitas Subang suparmanade09@gmail.com

\begin{abstract}
Abstrak
Retribusi pasar merupakan termasuk retribusi jasa umum yang dipungut dari pedagang atas penggunaan fasilitas pasar dan pemberian izin penempatan oleh Pemerintah Kabupaten Kota. Jadi retribusi pasar terdiri dari retribusi izin penempatan, retribusi kios, retribusi los, retribusi dasaran, dan retribusi tempat parkir. Retribusi pasar merupakan imbal jasa atas penyediaan sarana pasar oleh pemerintah, oleh karenanya retribusi pasar memiliki peran yang berarti terhadap fungsi pelayanan pemerintah kepada publik dan peningkatan kegiatan ekonomi masyarakat. Berdasarakan penelitian, diperoleh hasil bahwa Kinerja Bidang Pengelolaan Pasar Dalam Pemungutan Retribusi Pasar pada Dinas Koperasi, UMKM, Perdagangan Dan Perindustrian Kabupaten Subang secara umum belum optimal. Faktor-faktor yang menjadi hambatan Kinerja Bidang Pengelolaan Pasar Dalam Pemungutan Retribusi Pasar pada Dinas Koperasi, UMKM, Perdagangan Dan Perindustrian Kabupaten Subang adalah sarana dan prasarana dan partisipasi pedagang.

Kata Kunci : Kinerja Bidang Pengelolaan Pasar Dalam Pemungutan Retribusi Pasar pada Dinas Koperasi, UMKM, Perdagangan Dan Perindustrian Kabupaten Subang.
\end{abstract}




\begin{abstract}
Market levies constitute a general service levy collected from traders on the use of market facilities and granting placement permits by the Municipal Municipal Government. So the market levy consists of placement permit levies, kiosk retribution, retribution los, retribution, and parking levy. The market levy is a reward for the provision of market tools by the government, therefore market retribution has a significant role in the functioning of government services to the public and the improvement of the economic activities of the people. Based on the research, obtained the result that the Performance of Market Management in the Collection of Market Levies at the Department of Cooperatives, SMEs, Trade and Industry Subang Regency in general is not optimal. Factors that become obstacles of Market Management Performance in Market Levy Levy on Department of Cooperatives, SMEs, Trade and Industry Subang Regency is a means and infrastructure and the participation of traders.
\end{abstract}

Keywords: Market Management Performance In Collection of Market Levy at Department of Cooperatives, UMKM, Trade and Industry Subang Regency.

\title{
Pendahuluan
}

Penyelenggaraan pemerintahan daerah diarahkan untuk mempercepat terwujudnya kesejahteraan masyarakat melalui peningkatan pelayanan, pemberdayaan, dan peran serta masyarakat, serta peningkatan daya saing daerah dengan memperhatikan prinsip demokrasi, pemerataan, keadilan, dan kekhasan suatu daerah dalam sistem Negara Kesatuan Republik Indonesia. efisiensi dan efektivitas penyelenggaraan pemerintahan daerah perlu ditingkatkan dengan lebih memperhatikan aspek - aspek hubungan antara Pemerintah Pusat dengan daerah dan antar daerah, potensi dan keanekaragaman daerah, serta peluang dan tantangan persaingan global dalam kesatuan sistem penyelenggaraan pemerintahan negara. Undang-Undang Republik Indonesia Nomor 23 Tahun 2014 Tentang Pemerintahan Daerah, membawa implikasi yang mendasar terhadap penyelenggaraan pemerintahan di daerah. Sebagai pijakan pelaksanaan otonomi daerah secara nyata, luas dan tanggung jawab. Keleluasaan yang lebih nyata melalui kewenangan yang lebih luas diberikan kepada pemerintah daerah untuk mengurus rumah tangganya sendiri. Melalui otonomi diharapkan daerah menjadi mandiri di dalam pengelolahan kewenangan yang ditandai dengan makin kuatnya kepastin fiskal Pendapatan Asli Daerah (PAD) suatu daerah. Sementara itu untuk beberapa hal yang mungkin masih kekurangan dana, daerah masih diberi bantuan dari 
pemerintahan pusat dalam bentuk Dana Perimbangan. Namun tujuan awal pelaksanaan otonomi adalah mewujudkan kapasitas fiskal daerah yang kuat dalam mendungkung terciptanya kemandirian daerah. Untuk merealisasikan pelaksanaan otonomi daerah, maka sumber pembiayaan pemerintah daerah tergantung pada peran Pendapatan Asli Daerah (PAD). Berdasarkan Undang-Undang Nomor 33 Tahun 2004 tentang Perimbangan Keuangan antara Pemerintah Pusat dan Pemerintah Daerah disebutkan sumber-sumber Pendapatan Asli Daerah terdiri dari pajak daerah, retribusi daerah, hasil pengelolaan kekayaan daerah yang dipisahkan, dan lain-lain PAD yang sah. Oleh karena itu, pemerintah daerah harus dapat mengupayakan pengelolaan sumber-sumber penerimaan PAD secara optimal, sehingga akan tersedianya keuangan daerah yang dapat digunakan untuk berbagai kegiatan pembangunan. Kewenangan yang lebih leluasa yang dimiliki oleh pemerintah daerah otonomi daerah sesungguhnya merupakan kesempatan untuk pemerintah daerah mengembangkan sumber-sumber penerimaan daerahnya guna menyelnggarakan pemerintahan sendiri. Pengembangan sumber-sumber penerimaan daerah sendiri, retribusi, hasil perusahaan milik darah dan hasil pengelolaan hasil kekayaan daerah lainnya, dan lain-lain PAD yang sah merupakan salah satu ukuran kemampuan pemerintah daerah dalam menjalankan otonomi daerah. Mardiasmo (2002 : 215) mengatakan bahwa sebelum era otonomi harapan yang besar dari pemerintah daerah untuk dapat membangun daerah berdasarkan kemampuan dan kehendak daerah sendiri ternyata dari tahhun ketahun dirasakan semakin jauh dari kenyataan. Menurutnya, yang terjadi adalah ketergantungan fiskal dan subsidi serta bantuan pemerintah pusat sebagai wujud ketidak berdayaan PAD dalam membiayaai belanja daerah. Namun demikian, pemerintah daerah seperti kesulitan untuk mengembangkan sumber-sumber pendapatannya sendiri dan ketergantungan kepada pemerintah pusat tidak berkurang bahkan sebaliknya semakin menguat. Sumber-sumber pendapatan asli pendapatan asli daerah memiliki kontribusi yang rendah terhadap penerimaan daerah. Upaya mengembangkan sumber-sumber pendapatan sendiri baik melalui pajak daerah, retribusi daerah maupun hasil pengelolaan kekayaan daerah yang dipisahkan maupun lain-lain PAD yang sah, tidak sepenuhnya berhasil dilakukan oleh banyak pemerintah daerah.

Retribusi pasar merupakan termasuk retribusi jasa umum yang dipungut dari pedagang atas penggunaan fasilitas pasar dan pemberian izin penempatan oleh Pemerintah Kabupaten Kota. Jadi retribusi pasar terdiri dari retribusi izin penempatan, retribusi kios, retribusi los, retribusi dasaran, dan retribusi tempat parkir. Retribusi pasar merupakan imbal jasa atas penyediaan sarana pasar oleh pemerintah, oleh karenanya retribusi pasar memiliki peran yang berarti terhadap fungsi pelayanan pemerintah kepada publik dan peningkatan kegiatan ekonomi masyarakat. Peluang untuk meningkatkan penerimaan daerah terbuka jika penerimaan retribusi pasar mampu dioptimalkan. Hasil retribusi pasar sesungguhnya akan kembali melalui pengalokasian sumber dana untuk pembangunan, perbaikan dan perawatan Untuk itu usaha-usaha untuk meningkatkan penerimaan retribusi pasar menjadi penting adanya. 
Dengan demikian retribusi memiliki sifat pelayanan yang lebih nyata kepada publik. Dalam Pemungutan retribusi pasar perlu memperhatikan faktor-faktor yang mempengaruhinya. Retribusi pasar dipengaruhi oleh faktor jumlah pedagang, luas los dan kios, dan jumlah petugas pemungut retribusi . Semakin banyak jumlah pedagang, luas kios, los, dan dasaran terbuka serta jumlah petugas pemungut retribusi maka peranan penerimaan retribusi pasar akan semakin besar. Dinas Koperasi, UMKM, Perdagangan dan Perindustrian Kabupaten Subang merupakan salah satu lembaga pemerintah yang mempunyai tugas pokok dan fungsi melaksanakan kewenangan otonomi di Bidang Pengelolaan Pasar dan tugas pembantuan yang ditugaskan kepada Pemerintah Daerah. Bidang Pengelolaan Pasar mempunyai tugas pokok melakukan kegiatan pengelolaan retribusi, keamanan dan kebersihan serta pengawasan dan pengembangan pasar.

Dinas Koperasi, UMKM, Perdagangan dan Perindustrian Kabupaten Subang telah memiliki program kerja dalam pengelolaan retribusi pasar yang didasarkan pada Peraturan Daerah Kabupaten Subang No 5 Tahun 2012. Dalam pelaksanaan peraturan tersebut memuat antara lain meliputi Penyusunan rencana kegiatan pengelolaan retribusi pasar, Pengumpulan, pengolahan dan penganalisaan data dalam rangka pengelolaan retribusi pasar, Penyelenggaraan kegiatan pengelolaan retribusi pasar, Pemberian pelayanan usaha dibidang perpasaran, Pelaksanaan pembinaan bimbingan dan penyuluhan dalam rangka peningkatan dari sektor pasar, Pengelolaan administrasi hasil-hasil pendapatan dari sector pasar, Pelaksanaan bimbingan dan pengawasan terhadap pengaturan pendapatan pasar dari unit pasar. Berdasarkan hasil observasi yang peneliti lakukan, diperoleh bahwa kinerja Bidang Pengelolaan Pasar Dinas Koperasi, UMKM, Perdagangan dan Perindustrian Kabupaten Subang pemungutan retribusi pasar belum optimal. Hal ini terlihat dari indikator-indikator sebagai berikut: Dalam Pemungutan Retribusi Pasar menunjukkan bahwa pada tahun 2013, 2014 dan 2016 realisasi penerimaan retribusi pasar tidak mencapai targetnya mengindikasikan adanya permasalahan Dalam penerimaan retribusi pasar masih belum optimal. Terbukti dari selama empat tahun (2013-2016) pada tahun 2013, 2014 dan tahun 2016 realisasi retribusi pasar tidak mencapai target. Pada tahun 2013 hanya sampai 95\% dan tahun 2015 mencapai 91\% dan tahun 2016 .

\section{Kerangka Teori}

\section{a. Konsep Kinerja}

Kinerja berasal dari pengertian performance. Adapula yang memberikan pengertian performance sebagai hasil kerja atau prestasi kerja. Namun, sebenarnya kinerja mempunyai makna yang lebih luas, bukan hanya hasil kerja, tetapi termasuk bagaimana proses pekerjaan berlangsung. Kinerja merupakan suatu hasil yang diperoleh dari seseorang atau pekerja setelah dia melakukan sesuatu dalam hal ini 
peerjaannya. Kinerja merupakan istilah yang berasal dari kata Job performance atau Actual Performance (prestasi kerja atau prestasi sesungguhnya yang dicapai seseorang). Pengertian kinerja dalam organisasi merupakan jawaban dari berhasil atau tidaknya tujuan organisasi yang telah ditetapkan. Berikut adalah definisi dan penjelasan mengenai kinerja menurut para ahli. Menurut Mangkunegara (2010 : 9) mendefinisikan " Kinerja (prestasi kerja) adalah hasil kerja secara kualitas dan kuantitas yang dicapai oleh seseorang pegawai dalam melaksanakan tugasnya sesuai dengan tanggung jawab yang diberikan kepadanya." Prestasi kerja sesungguhnya keberhasilan yang dicapai oleh seseorang atau suatu institusi organisasi pemerintahan. Berhasil atau tidaknya tujuan dalam organisasi pemerintahan tergantung bagaimana pegawai dalam melaksanakan tugasnya sesuai tanggung jawab yang diberikan kepadanya. Masih dalam Mangkunegara (2010: 9) Faustino Cardosa Gomes mendefinisikn bahwa "Kinerja adalah sebagai ungkapan seperti output, efisiensi serta efektivitas sering dihubungkan dengan produktivitas." Hasil kerja organisasi diperoleh dari serangkaian aktivitas yang dijalankan organisasi. Aktivitas organisasi dapat berupa pengelolaan sumber daya organisasi maupun proses pelaksanaan kerja yang diperlukan untuk mencapai tujuan organisasi. Dari beberapa pendapat diatas disimpulkan bahwa kinerja adalah prestasi kerja atau hasil kerja (output) yang dicapai oleh seseorang atau institusi baik kualitas maupaun kuantitas yang dicapai persatu periode waktu dalam melaksanakan tugas kerjanya sesuai dengan tanggung jawab yang diberikan kepadanya. Kemudian Amstrong dan Baron dalam wibowo (2008 : 7) mengemukakan bahwa Kinerja merupakan hasil pekerjaan yang mempunyai hubungan kuat dengan tujuan strategis organisasi, kepuasan konsumen dan memberikan kontribusi ekonomi." Artinya kinerja adalah tentang melakukan pekerjaan dan hasil kerja yang dicapai dari pekerjaan tersebut, tentang apa yang dikerjakan dan bagaimana cara mengerjakannya. Penulis menyimpulkan bahwa kinerja merupakan hasil kerja yang dicapai seseorang secara kualitas maupun kuantitas dalam fungsi pekerjaan atau aktivitas selama jangka waktu tertentu dan berhubungan dengan kepuasan konsumen

\section{b. Pengertian Organisasi}

Organisasi merupakan suatu struktur pembagian kerja dan struktur tata hubungan kerja antara sekelompok orang pemegang posisi yang bekerjasama secara tertentu untuk bersama-sama mencapai tujuan tertentu. Untuk lebih jelasnya penulis akan mengemukakan beberapa pengertian organisasi antara lain menurut Louis A. Allen (dalam Abdulsyani, 1993 : 116) menyatakan bahwa Organisasi sebagai proses penentuandan pengelompokan pekerjaan yang akan dilakukan, menetapkan dan melimpahkan wewenang dan tanggung jawab, dengan maksud untuk memungkinkan orang-orang bekerja sama secara efektif dalam mencapai tujuan. Selanjutnya pengerian yang dikemukakan oleh Edgar Schein (dalam Sutarto, 1933 : 35) bahwa organsasi adalah koordinasi yang rasional dan aktivitas-aktivitas 
sejumlah orang untuk mencapai beberapa tujuan yang jelas, melalui pembagian kerja dan fungsi serta fungsi melalui jenjang wewenang dan tanggungjawab. Dari pendapat tersebut dapat disipulkan bahwa organisasi pada dasarnya merupakan proses kerjasama dan tanggungjawab terhadap semua anggota organisasi agar dapat meningkatkan kinerja pegawai dalam rangka mencapai tujuan organisasi. Kemudian pengertian organisasi menurut Armosudiro (2006:12) yaitu sebagai berikut : "organisasi ialah setiap bentuk persekutuan antara dua orang atau lebih yang bekerja bersama serta secara formal terikat dalam rangka pencapaian suatu tujuan yang telah ditentukan dalam ikatan yang mana terdapat seseorang / beberapa orang yang disebut atasan dan seorang / sekelompok orang yang disebut dengan bawahan." Berdasarkan pengertian diatas Organisasi adalah sekelompok orang (dua atau lebih) yang secara formal dipersatukan dalam suatu struktur pembagian kerja dan struktur tata hubungan kerja antara sekelompok orang yang bekerjasama untuk mencapai tujuan yang telah ditetapkan. Suatu organisasi di bentuk karena mempunyai dasar dan tujuan yang ingin dicapai. Sebuah organisasi dapat terbentuk karena dipengaruhi oleh beberapa aspek seperti penyatuan visi dan misi serta tujuan yang sama dengan perwujudan eksistensi sekelompok orang tersebut terhadap masyarakat. Organisasi yang dianggap baik adalah organisasi yang dapat diakui keberadaannya oleh masyarakat disekitarnya, karena memberikan kontribusi seperti pengambilan sumber daya manusia dalam masyarakat sebagai anggota-anggotanya sehingga menekan angka pengangguran.

\section{c. Pengertian Kinerja Organisasi}

Kinerja organisasi merupakan indikator tingkatan prestasi yang dapat dicapai dan mencerminkan keberhasilan suatu organisasi, serta merupakan hasil yang dicapai dari perilaku anggota organisasi. Kinerja bisa juga dikatakan sebagai sebuah hasil (output) dari suatu proses tertentu yang dilakukan oleh seluruh komponen organisasi terhadap sumber-sumber tertentu yang digunakan (input). Kinerja merupakan produk dari kegiatan administratif, yaitu kegiatan kerjasama untuk mencapai tujuan yang pengelolaannya bisa disebut sebagai manajemen. Sedangkan organisasi adalah sekelompok orang (dua atau lebih) yang secara formal dipersatukan dalam suatu kerja sama untuk mencapai tujuan yang secara formal dipersatukan dalam suatu kerjasama untuk mencapai tujuan yang telah ditetapkan. Jadi kinerja organisasi adalah hasl kerja yang dihadapkan didalam suatu organisasi dalam mencapai tujuan yang telah ditetapkan. Kinerja organisasi mempunyai banyak pegertian. Wibawa, Atmosudirjo dalam Pasolong (2008 : 176), mengemukakan bahwa "kinerja organisasi adalah sebagai efektifitas organisasi secara menyeluruh untuk kebutuhan yang ditetapkan dari setiap kelompok yang berkenaan melalui usaha-usaha yang sistematik dan meningkatkan kemampuan organisasi secara terus menerus untuk mencapai kebutuhannya secara efektif". Artinya kinerja organisasi merupakan suatu capaian hasil kerja dalam kegiatan organisasi melalui aktivitas atau program yang telah direncanakan sebelumnya 
dengan seefektif mungkin melalui usaha-usaha yang terarah guna mencapai tujuan serta sasaran yang telah ditetapkan oleh suatu organisasi untuk mencapai kebutuhannya. Sedangkan pengertian kinerja organisasi menurut pendapat Surjadi (2009 : 7), yaitu sebagai berikut : "Kinerja organisasi adalah totalitas hasil kerja yang dicapai suatu organisasi tercapainya tujuan organisasi berarti bahwa, kinerja suatu organisasi itu dapat dilihat dari tingkatan sejauh mana organisasi dapat mencapai tujuan yang didasarkan pada tujuan yang sudah ditetapkan sebelumnya". Berdasakan pengertian diatas kinerja juga merupakan hasil dari totalitas serangkaian proses kegiatan yang dilakukan untuk mencapai tujuan tertentu organisasi. Bagi suatu organisasi, kinerja merupakan hasil dari kegiatan kerjasama diantara anggota atau komponen organisasi dalam rangka mewujudkan tujuan yang telah ditetapkan sebelumnya dalam organisasi. Menurut Sobandi (2006:176) Kinerja organisasi merupakan sesuatu yang telah dicapai oleh organisasi dalam kurun waktu tertentu, baik yang terkait dengan input, output, outcome, benefit, maupun impact. Hasil kerja yang dicapai oleh suatu instansi dalam menjalankan tugasnya dalam kurun waktu tertentu, baik yang terkait dengan input, output, outcome, benefit, maupun impact dengan tanggung jawab dapat mempermudah arah penataan organisasi pemerintahan. Adanya hasil kerja yang dicapai oleh instansi dengan penuh tanggung jawab akan tercapai peningkatan kinerja yang efektif dan efisien. . Sedangkan menurut mahsun (2006 : 25) kinerja organisasi adalah gambaran mengenai tingkat pencapaian pelaksanaan suatu organisasi/program/kebijakan dalam mewujudkan sasaran, tujuan, visi dan misi organisasi yang tertuang dalam strategic planning suatu organisasi. Dari definisi diatas dapat dipahami bahwa kinerja organisasi adalah seberapa jauh tingkatan kemampuan pelaksana tugastugas organisasi dalam rangka pencapaian tujuan sesuai dengan kemampuan yang dimiliki dan program/kebijakan /visi dan misi yang telah ditetapkan sebelumnya. Kinerja suatu organisasi dapat dilihat dari tingkatan sejauh mana organisasi dapat mencapai tujuan yang didasarkan pada visi dan misi yang sudah ditetapkan sebelumnya. Untuk itu, diperlukan beberapa informasi tentang kinerja organisasi. Informasi tersebut dapat digunakan untuk melakukan evaluasi terhadap proses kerja yang dilakukan organisasi selama ini, sudah sejalan dengan tujuan yang diharapkan atau belum. Berdasarkan definisi diatas mengenai pengertian kinerja organisasi didapat kesimpulan bahwa kinerja organisasi penilaian terhadap seberapa jauh tingkatan kemampuan pelaksana tugas-tugas organisasi dalam rangka pencapaian tujuan sesuai dengan kemampuan yang dimiliki dan program/kebijakan /visi dan misi yang telah ditetapkan sebelumnya.

\section{d. Faktor-faktor yang mempengaruhi kinerja}

Dalam menilai kinerja organisasi tidak lepas dari faktor-faktor dari dalam maupun yang ada disekeliling organisasi yang dapat mempengaruhi kinerja organisasi tersebut. Menurut Mahmudi (2005 : 21) kinerja merupakan suatu 
konstruk multidimensional yang mencakup banyak faktor yang mempengaruhinya. Faktor-faktor yang mempengaruhi kinerja adalah :

a) Faktor personal/individual, meliputi : pengetahuan, keterampilan, kemampuan, kepercayaan diri, motivasi, dan komitmen yang dimiliki oleh setiap individu.

b) Faktor kepemimpinan, meliputi : kualitas dalam memberikan dorongan, semangat, arahan dan dukungan yang diberikan manajer dan team leader.

c) Faktor tim, meliputi : kualitas dukungan dan semangat yang diberikan oleh rekan dalam satu tim, kepercayaan terhadap sesama anggota tim, kekompakan dan keeratan anggota tim.

d) Faktor sistem, meliputi : sistem kerja, fasilitas kerja atau infrastruktur yang diberikan oleh organisasi, proses organisasi, dan kultur kinerja dalam organisasi.

e) Faktor kontekstual, meliputi : tekanan dan perubahan lingkungan eksternal dan internal.

Menurut Soesilo dalam Hessel (2005:180) mengemukakan bahwa kinerja suatu organisasi di masa depan dipengaruhi oleh faktor-faktor berikut :

a) Struktur organisasi sebagai hubungan internal yang berkaitan dengan fungsi yang menjalankan aktivitas organisasi.

b) Kebijakan pengelolaan, berupa visi dan misi organisasi.

c) Sumber daya manusia, yang berkaitan dengan kualitas karyawan untuk bekerja dan berkarya secara optimal.

d) Sistem informasi manajemen, yang berhubungan dengan pengelolaan data base untuk digunakan dalam mempertinggi kinerja organisasi.

e) Sarana dan prasarana yang dimiliki, yang berhubungan dengan penggunaan teknologi bagi penyelenggara organisasi pada setiap aktivitas organisasi.

Ruky dalam Hessel (2005:180) mengidentifikasi faktor-faktor yang berpengaruh langsung terhadap tingkat pencapaian kinerja organisasi sebagai berikut :

a) Teknologi yang meliputi peralatan kerja dan metode kerja yang digunakan untuk menghasilkan produk atau jasa yang dihasilkan oleh organisasi. Semakin berkualitas teknologi yang digunakan maka akan semakin tinggi tingkat kinerja organisasi tersebut.

b) Kualitas input atau material yang digunakan oleh organisasi.

c) Kualitas lingkungan fisik yang meliputi keselamatan kerja, penataan ruangan dan kebersihan.

d) Budaya organisasi sebagai pola tingkah laku dan pola kerja yang ada dalam organisasi yang bersangkutan.

e) Kepemimpinan sebagai upaya untuk mengendalikan anggota organisasi agar bekerja sesuai dengan standart dan tujuan organisasi.

f) Pengelolaan sumber daya manusia yang meliputi aspek kompensasi, imbalan, promosi, dan lain-lain.

Sementara itu, Dale Timpe (2001: 26) menyebutkan tiga penentu kinerja organisasi yaitu tingkat keterampilan, tingkat upaya dan kondisikondisi eksternal. Sehingga dapat diambil kesimpulan bahwa faktor yang mempengaruhi kinerja 
organisasi dapat ditujukan pada faktor sumber daya manusia, struktur organisasi dan komunikasi organisasi.

\section{e. Indikator Kinerja Organisasi}

Indikator Kinerja Organisasi yang digunakan untuk mengukur kinerja organisasi publik (Moeheriono, $2010: 80$ ) yaitu sebagai berikut :

a) Efektivitas, Indikator ini mengukur derajat kesesuaian output yang dihasilkan dalam mencapai sesuatu yang diinginkan. Indikator mengenai efektivitas ini menjawab pertanyaan mengenai apakah kita melakukan sesuatu yang sudah benar (are we doing the right things ?)

b) Efisiensi, indikator ini mengukur derajat kesesuaian proses menghasilkan output dengan menggunakan biaya serendah mungkin. Indikator mengenai efektivitas menjawab pertanyaan mengenai kita melakukan sesuatu dengan benar (we are doing things right?).

c) Kualitas, indikator ini mengukur derajat kesesuaian antara kualitas produk atau jasa yang dihasilkan dengan kebutuhan dan harapan konsumen.

d) Ketepatan waktu. Indikator ini mengukur apakah pekerjaan diselesaikan secara benar dan tepat waktu. Untuk itu, perlu ditentukan kriteria yang dapat mengukur berapa lama waktu yang seharusnya diperlukan untuk menghasilkan suatu produk. kriteria ini biasanya didasarkan pada harapan konsumen.

e) Produktivitas. Indikator ini mengukur tingkat produktivitas suatu organisasi. Dalam bentuk yang lebih ilmiah, indikator ini mengukur nilai tambah yang dihasilkan oleh suatu proses dibandingkan dengan nilai yang dikonsumsi untuk biaya modal dan tenaga kerja.

Kinerja organisasi sebenarnya dapat dilihat melalui berbagai dimensi seperti dimensi efektivitas, efisiensi, kualitas, ketepatan waktu maupun produktivitas. Berbagai literatur yang membahas kinerja organisasi publik pada dasarnya memiliki kesamaan substansial yakni untuk melihat seberapa jauh tingkat pencapaian hasil yang telah dilakukan oleh birokrasi pelayanan. Kinerja itu merupakan suatu konsep yang disusun dari berbagai indikator yang sangat bervariasi sesuai dengan fokus dan konteks penggunaannya.

\section{Metode Penelitian}

Penelitian ini menggunakan pendekatan kualitaif. Menurut (Creswell, 2010:4) penelitian kualitatif merupakan metode-metode untuk mengeksplorasi dan memahami makna yang oleh sejumlah individu atau sekelompok orang dianggap berasal dari masalah sosial atau kemanusiaan. Proses penelitian ini melibatkan upaya-upaya penting seperti mengajukan pertanyaan-pertanyaan dan prosedur-prosedur mengumpulkan data spesifik dari pertisipa, menganalisis data secara induktif melalui tema-tema yang khusus ke tema-tema yang umum, dan menafsirkan makna dari data. 
Adapun alasan pemilihan metode kualitatif adalah kondisi ingin mendalami bagaimana Kinerja Bidang Pengelolaan Pasar Dalam Pemungutan Retribusi Pasar pada Dinas Koperasi, UMKM, Perdagangan Dan Perindustrian Kabupaten Subang.

\section{Hasil dan Pembahasan}

a. Dinas Koperasi, UMKM, Perdagangan dan Perindustrian Kabupaten Subang

Dinas Perindustrian, Perdagangan dan Pengelolaan Pasar Kabupaten Subang telah dibentuk dengan Peraturan Daerah Kabupaten Subang Nomor 7 Tahun 2008 Tentang Organisasi dan Tata Kerja Dinas Daerah di Lingkungan Pemerintah Kabupaten Subang. bahwa berdasarkan ketentuan Pasal 17 Peraturan Daerah termaksud perlu menetapkan Tugas dan Fungsi Dinas Perindustrian, Perdagangan dan Pengelolaan Pasar Kabupaten Subang dengan Peraturan Bupati Subang. Mengalami perubahan bahwa untuk melaksanakan ketentuan pasal 9 Peraturan Daerah Kabupaten Subang Nomor 7 Tahun 2016 tentang Pembentukan dan Susunan Perangkat Daerah Kabupaten Subang, menetapkan Peraturan Bupati Subang Nomor : 57 Tahun 2016 tentang Tugas Pokok, Fungsi dan Tata Kerja Dinas Koperasi, UMKM, Perdagangan dan Perindustrian Kabupaten Subang. Tugas pokok dari Dinas Koperasi, UMKM, Perdagangan dan Perindustrian Kabupaten Subang adalah melaksanakan kewenangan daerah di bidang Koperasi, UMKM, Perdagangan dan Perindustrian Kabupaten Subang yang menjadi kewenangan daerah dan tugas pembantuan yang diberikan kepada Pemerintah Kabupaten Subang.

Fungsi Dinas Koperasi, UMKM, Perdagangan dan Perindustrian Kabupaten Subang itu sendiri adalah :

a) Perumusan kebijaksanaan teknis di bidang Koperasi, UMKM, Perdagangan dan Perindustrian Kabupaten Subang ;

b) Penyelenggaraan urusan pemerintahan dan pelayanan umum dibidang Koperasi, UMKM, Perdagangan dan Perindustrian Kabupaten Subang sesuai dengan ketentuan yang ditetapkan oleh Bupati ;

c) Pembinaan dan pelaksanaan kegiatan dibidang Koperasi, UMKM, Perdagangan dan Perindustrian Kabupaten Subang ;

d) Pengelolaan administrasi umum, meliputi urusan umum, urusan keuangan, urusan kepegawaian dan perlengkapan dinas.

Visinya yaitu "Mewujudkan industri kecil menengah dan perdagangan pengelolaan hasil pertanian komoditi unggulan yang berorientasi terhadap pasar serta menjadi penggerak ekonomi daerah Kabupaten Subang tahun 2024". Adapun misi Dinas ini adalah : 
1) Mendorong perkembangan industri pada Sub sistem industri hulu dan sistem pengelolaan hasil pertanian serta industri manufaktur dengan memanfaatkan kestrategisan.

2) Memperkuat daya saing, inovasi, kualitas produk agro bisnis dan manufaktur guna menungkatkan pemasaran.

3) Meningkatkan perkembangan industri besar dan ikm melalui program pembinaan dan memaduserasikan industri manufaktur, agro, ikm dengan arah perkembangan wilayah dan tata ruang

4) Mengamankan arus distribusi barang dan tata niaga yang sehat serta meningkatkan perlindungan konsumen dan produsen.

5) Mewujudkan fungsi pasar sebagai tempat utama yang khas, nyaman dan bersaing.

\section{b. Kinerja Bidang Pengelolaan Pasar Dalam Pemungutan Retribusi Pasar Pada Dinas Koperasi, UMKM, Perdagangan Dan Perindustrian Kabupaten Subang.}

Kinerja/performance adalah hasil kerja yang dapat dicapai oleh sesorang atau sekelompok orang dalam suatu organisasi sesuai dengan wewenang dan tanggung jawab masing-masing dalam rangka upaya mencapai tujuan organisasi yang bersangkutan secara legal, tidak melanggar hukum dan sesuai dengan moral dan etika. Pengukuran kinerja merupakan salah satu faktor penting dalam meningkatkan kualitas pelayanan sebuah organisasi. Rancangan sistem pegukuran kinerja yang akurat dan konstektual merupakan arah menuju sebuah organisasi itu dapat unggul dan handal. Dinas Koperasi, UMKM, Perdagangan Dan Perindustrian Kabupaten Subang adalah suatu organisasi yang bergerak dalam bidang pelayanan terhadap masyarakat. Karena itulah kinerja Dinas Koperasi, UMKM, Perdagangan Dan Perindustrian Kabupaten Subang dituntut untuk memberikan pelayanan yang optimal dengan kinerja yang baik. Kinerja Bidang Pengelolaan Pasar Dalam Pemungutan Retribusi Pasar Pada Dinas Koperasi, UMKM, Perdagangan Dan Perindustrian Kabupaten Subang yang baik sangat berpengaruh terhadap pelayanan publik yang mengutamakan kepuasan masyarakat. Bidang Pengelolaan Pasar Dalam Pemungutan Retribusi Pasar Pada Dinas Koperasi, UMKM, Perdagangan Dan Perindustrian Kabupaten Subang mempunyai peran yang sangat penting dalam sistem pemerintahan karena di sini Dinas Koperasi, UMKM, Perdagangan Dan Perindustrian Kabupaten Subang berhubungan langsung dengan masyarakat. Kinerja dalam organisasi publik pun harus tercipta dengan baik agar dalam penyelengaraan dapat berjalan efektif dalam melayani masyarakat. Dinas Koperasi, UMKM, Perdagangan Dan Perindustrian Kabupaten Subang pastinya akan mengadakan perbaikan dan peningkatan dalam peningkatan pengelolan pasar. Kenyataannya terkadang perbaikan dan peningkatan itu masih dinilai kurang. Peningkatan kinerja dalam suatu instansi merupakan faktor utama untuk 
meningkatkan kualitas Sumber Daya Manusia (SDM) berkualitas merupakan faktor yang dapat mempengaruhi peningkatan kinerja organisasi publik dalam memberikan pelayanan kepada masyarakat. Akibat dari globalisasi itu sendiri harus dapat dimanfaatkan dengan baik. Akibat yang ditimbulkan dari globalisasi belum tentu positif. Serta dengan adanya kemajuan di bidang Ilmu Pengetahuan dan Teknologi (IPTEK), sangat membutuhkan Sumber Daya Manusia (SDM) yang berkualitas agar dapat memanfaatkan dan mengolah segala perkembangan tersebut. Selain itu, perkembangan dan kemajuan di atas menjadikan peningkatan proses empowering dalam lingkungan masyarakat. Oleh karena itu pelayanan pasar yang dilakukan oleh Bidang Pengelolaan Pasar juga diharapkan mengikuti perubahanperubahan yang terjadi secara cepat dan dinamis sebagaimana yang terjadi di masyarakat. Kinerja Bidang Pengelolaan Pasar Dalam Pemungutan Retribusi Pasar Pada Dinas Koperasi, UMKM, Perdagangan Dan Perindustrian Kabupaten Subang merupakan kemampuan Kinerja Bidang Pengelolaan Pasar Dalam Pemungutan Retribusi Pasar termasuk di dalamnya kinerja pimpinan, kinerja pegawai dan stafstafnya dalam menjalankan fungsi dan tugas dalam mencapai tujuan yang ingin dicapai sesuai dengan visi, misi, tujuan dan sasarannya.

Dinas Koperasi, UMKM, Perdagangan dan Perindustrian Kabupaten Subang telah memiliki program kerja dalam pengelolaan retribusi pasar yang didasarkan pada Peraturan Daerah Kabupaten Subang No 5 Tahun 2012. Dalam pelaksanaan peraturan tersebut memuat antara lain meliputi Penyusunan rencana kegiatan pengelolaan retribusi pasar, Pengumpulan, pengolahan dan penganalisaan data dalam rangka pengelolaan retribusi pasar, Penyelenggaraan kegiatan pengelolaan retribusi pasar, Pemberian pelayanan usaha dibidang perpasaran, Pelaksanaan pembinaan bimbingan dan penyuluhan dalam rangka peningkatan dari sektor pasar, Pengelolaan administrasi hasil-hasil pendapatan dari sector pasar, Pelaksanaan bimbingan dan pengawasan terhadap pengaturan pendapatan pasar dari unit pasar.

Retribusi pasar merupakan termasuk retribusi jasa umum yang dipungut dari pedagang atas penggunaan fasilitas pasar dan pemberian izin penempatan oleh Pemerintah Kabupaten Kota. Jadi retribusi pasar terdiri dari retribusi izin penempatan, retribusi kios, retribusi los, retribusi dasaran, dan retribusi tempat parkir. Retribusi pasar merupakan imbal jasa atas penyediaan sarana pasar oleh pemerintah, oleh karenanya retribusi pasar memiliki peran yang berarti terhadap fungsi pelayanan pemerintah kepada publik dan peningkatan kegiatan ekonomi masyarakat. Peluang untuk meningkatkan penerimaan daerah terbuka jika penerimaan retribusi pasar mampu dioptimalkan. Hasil retribusi pasar sesungguhnya akan kembali melalui pengalokasian sumber dana untuk pembangunan, perbaikan dan perawatan Untuk itu usaha-usaha untuk meningkatkan penerimaan retribusi pasar menjadi penting adanya. Dengan demikian retribusi memiliki sifat pelayanan yang lebih nyata kepada publik. Dalam Pemungutan retribusi pasar perlu memperhatikan faktor-faktor yang 
mempengaruhinya. Retribusi pasar dipengaruhi oleh faktor jumlah pedagang, luas los dan kios, dan jumlah petugas pemungut retribusi. Semakin banyak jumlah pedagang, luas kios, los, dan dasaran terbuka serta jumlah petugas pemungut retribusi maka peranan penerimaan retribusi pasar akan semakin besar. Penilaian suatu kinerja dalam organisasi dapat dijadikan sebagai ukuran keberhasilan suatu organisasi dalam mencapai misi yang ditetapkan. Sehingga penilaian kinerja sangat dianggap penting. Suatu pelayanan yang optimal adalah jika didalamnya terdapat indikator-indikator yang digunakan untuk tolak ukur keberhasilan.

Dalam kajian ini akan dibahas tentang hasil dan pembahasan dalam penelitian tentang Kinerja Bidang Pengelolaan Pasar Dalam Pemungutan Retribusi Pasar Pada Dinas Koperasi, UMKM, Perdagangan Dan Perindustrian Kabupaten Subang. Untuk mengukur Kinerja Bidang Pengelolaan Pasar Dalam Pemungutan Retribusi Pasar Pada Dinas Koperasi, UMKM, Perdagangan Dan Perindustrian Kabupaten Subang digunakan indikator-indikator Kinerja Organisasi Seperti efektif, efisien, kualitas, ketepatan waktu dan produktivitas. Selain itu juga akan dibahas faktorfaktor yang menjadi hambatan Kinerja Bidang Pengelolaan Pasar Dalam Pemungutan Retribusi Pasar Pada Dinas Koperasi, UMKM, Perdagangan Dan Perindustrian Kabupaten Subang.

\section{b. 1 Efektif}

Efektif adalah mengukur derajat kesesuaian output yang dihasilkan dalam mencapai sesuatu yang diinginnkan. Indikator mengenai Efektif ini menjawab pertanyaan mengenai apakah kita melakukan sesuatu yang sudah benar. Suatu organisasi dapat dikatakan Efektif kalau tujuan organisasi atau nilai-nilai sebagaimana ditetapkan dalam visinya tercapai. Nilai-nilai ini merupakan nilainiali yang tealah disepakati bersama antara para stakeholder dari organisasi yang bersangkutan. Karena itu pencapaian visi adalah indikator yang paling penting. Akan tetapi seringkali visi organisasi dapat tercapai namun bukan secara sengaja atau sebagaimana direncanakan. Karena itu perlu juga dinilai pengembangan misi organisasi dan keterkaitannya dengan pencapaian visi. Efektif organisasi menggambarkan sampai seberapa jauh suatu organisasi merealisasikan tujuan akhirnya (goals). Dalam pelaksanaanya Bidang Pengelolaan Pasar Dalam Pemungutan Retribusi Pasar Pada Dinas Koperasi, UMKM, Perdagangan Dan Perindustrian Kabupaten Subang harus sesuai dengan standar operasional prosedur yang telah ditentukan. Seperti wawancara yang dilakukan kepada Kepala Bidang Pengelolaan Pasar, sebagai berikut : "Dalam setiap melakukan tugasnya Bidang Pengelolaan Pasar Dalam Pemungutan Retribusi Pasar Pada Dinas Koperasi, UMKM, Perdagangan Dan Perindustrian Kabupaten Subang selalu memperhatikan SOP yang telah ditentukan. Karena SOP sebagai pijakan kami dalam pengeloaan retribusi pasar. Dinas Koperasi, UMKM, Perdagangan Dan Perindustrian Kabupaten Subang membuat petunjuk teknis dalam pengelolaan retribusi pasar". (Hasil Wawancara, Desember 2017 ). Mengenai standar operasional prosedur dalam 
pengelolaan retribusi pasar yang dilakukan oleh Dinas Koperasi, UMKM, Perdagangan Dan Perindustrian Kabupaten Subang menggunakan petunjuk teknis dalam pengelolaan retribusi pasar pada Peraturan Daerah Kabupaten Subang No 5 Tahun 2012. Dalam pelaksanaan peraturan tersebut memuat antara lain meliputi Penyusunan rencana kegiatan pengelolaan retribusi pasar, Pengumpulan, pengolahan dan penganalisaan data dalam rangka pengelolaan retribusi pasar, Penyelenggaraan kegiatan pengelolaan retribusi pasar, Pemberian pelayanan usaha dibidang perpasaran, Pelaksanaan pembinaan bimbingan dan penyuluhan dalam rangka peningkatan dari sektor pasar, Pengelolaan administrasi hasil-hasil pendapatan dari sector pasar, Pelaksanaan bimbingan dan pengawasan terhadap pengaturan pendapatan pasar dari unit pasar. Dinas Koperasi, UMKM, Perdagangan Dan Perindustrian Kabupaten Subang juga dapat dilihat dari pencapaian target pendapatan, seperti yang diungkapkan oleh kepala Bidang Pengelolaan Pasar berikut ini : “.....Targetnya yang pertama ya mestinya untuk pendapatannya, karena pendapatan Bidang Pengelolaan Pasar sebagai PAD (Pendapatan Asli Daerah Kabupaten Subang). Yang PAD tersebut kembali lagi ke masyarakat khususnya masyarakat Subang dalam rangka pengelolaan pasar yang optimal.." (Hasil Wawancara, Desember 2017 ). Ungkapan di atas dapat memberi penjelasan bahwa Dinas Koperasi, UMKM, Perdagangan Dan Perindustrian Kabupaten Subang tidak hanya mencari keuntungan semata melainkan tetap memperhatikan pelayanan yang diberikan kepada masyarakat. Hal ini dikarenakan pendapatan dari Dinas Koperasi, UMKM, Perdagangan Dan Perindustrian Kabupaten Subang sebagian disumbangkan untuk PAD (Pendapatan Asli Daerah Kabupaten Subang). Peningkatan pelayanan pasar kepada masyarakat juga menjadi target yang ditetapkan oleh Dinas Koperasi, UMKM, Perdagangan Dan Perindustrian Kabupaten Subang. Dinas Koperasi, UMKM, Perdagangan Dan Perindustrian Kabupaten Subang juga sangat memperhatikan kesejahteraan pegawai dan sumber daya manusia.

Tercapainya target yang telah ditentukan oleh Dinas Koperasi, UMKM, Perdagangan Dan Perindustrian Kabupaten Subang juga bisa meningkatkan kesejahtraan pegawai karena di Dinas Koperasi, UMKM, Perdagangan Dan Perindustrian Kabupaten Subang masih banyak pegawai yang belum menjadi PNS yang berarti gaji pegawai bersumber dari retribusi yang diberikan masyarakat. Dengan tercapainya target retribusi sampah diharapkan kualitas pelayanan juga perlu meningkat. Penetapan target bagi organisasi merupakan sarana untuk memacu organisasi tersebut dalam mencapai tujuannya. Masalah yang lebih sulit lagi adalah bagaimana pencapaian target tersebut, karena untuk mencapai target tersebut dipengaruhi beberapa faktor. Dinas Koperasi, UMKM, Perdagangan Dan Perindustrian Kabupaten Subang selalu melakukan peningkatan dalam berkinerja. Paningkatan itu tentu saja untuk mendukung pencapaian pengelolaan kebersihan yang baik. Seperti ungkapan Kepala Seksi Pengelolaan Pasar sebagai berikut : “......Untuk targetnya ya, di dalam pelayanan yang jelas kita selalu meningkatkan. 
Peningkatan setiap tahun ada. Kemudian yang kedua, target-target yang kita capai sesuai dengan rencana kerja itu kita selalu memperoleh hasil yang di atas dari rencana." (Hasil Wawancara, Desember 2017 ) Dari ungkapan di atas, dapat mempelihatkan bahwa dalam mencapai target, tentu saja harus diimbangi dengan peningkatan pelayanan kepada masyarakat. Bahkan peningkatan setiap tahunnya selalu ada. Pencapaian target Dinas Koperasi, UMKM, Perdagangan Dan Perindustrian Kabupaten Subang sesuai dengan rencana kerja dan hasil yang diperoleh, selalu di atas dari rencana awal. Dapat disimpulkan bahwa Dinas Koperasi, UMKM, Perdagangan Dan Perindustrian Kabupaten Subang dapat dikatakan sudah baik walaupun belum maksimal dan masih perlu ditingkatkan. Tidak lepas dari itu, Dinas Koperasi, UMKM, Perdagangan Dan Perindustrian Kabupaten Subang dalam pnerimaan retribusi pasar tentu saja harus melakukan sesuatu dengan benar sesuai derajat kesesuaian output yang dihasilkan dalam mencapai sesuatu yang diinginnkan, sehingga masyarakat masyarakat puas dengan pelayanan yang diberikan.

\section{b.2 Efisien}

Terselenggaranya kegiatan instansi publik dengan menggunakan sumber daya yang tersedia secara optimal dan bertanggung jawab. Indikatornya antara lain adalah pelayanan mudah, cepat, tepat dan murah. Cara yang dilakukan agar Dinas Koperasi, UMKM, Perdagangan Dan Perindustrian Kabupaten Subang dalam penerimaan retribusi pasar untuk menciptakan kondisi kinerja yang efisien guna terlaksananya penerimaan retribusi pasar melakukan pekerjaanya menggunakan biaya yang hemat sehingga menghasilkan output dengan menggunakan biaya serendah mungkin. Efisiensi adalah perbandingan rasio keluaran dengan masukan. Menurut (Tjokroamidjojo dalam Pasolong 2016 : 3) efisiensi adalah perbandingan yang terbaik antara input dan output atau perbandingan antara pengeluaran dan keuntungan. Misalnya hasil maksimum yang dicapai dengan penggunaan sumberdaya yang terbatas. Dengan kata lain perbandingan antara apa yang telah dihasilkan dengan apa yang seharusnya diselesaikan. Secara umum efisiensi mengandung pengertian sebagai rasio output yang dihasilkan terhadap input yang digunakan; atau dengan kata lain efisiensi merupakan perbandingan output dengan input dikaitkan dengan standar kinerja yang ditetapkan. Suatu kebijakan atau program dinyatakan efisien jika suatu target tertentu dapat dicapai dengan penggunaan sumber-sumber daya dan dana yang serendah-rendahnya diperbandingkan secara relatif terhadap kinerja usaha sejenis atau antar kurun waktu. Efisiensi dalam pemungutan retribusi pasar dilihat dari aspek-aspek : efisiensi penggunaan anggaran/dana, efisiensi penggunaan sarana/prasarana (peralatan), dan efisiensi penggunaan sumber daya manusia. Berdasarkan penelitian memberikan gambaran bahwa Dinas Koperasi, UMKM, Perdagangan Dan Perindustrian Kabupaten Subang penggunaan anggaran/dana untuk pengelolaan pasar sudah dilakukan dengan baik dan efisien. Efisiensi Jumlah pegawai / pekerja 
di Dinas Koperasi, UMKM, Perdagangan Dan Perindustrian Kabupaten Subang khususnya pekerja di Bidang Pengelolaan Pasar. Karena pekerja di Bidang Pengelolaan Pasar ini yang bergelut dalam aktivitas operasional pemungutan retribusi pasar dengan kegiatan mulai dari Pengelolaan Pasar dan tugas pembantuan yang ditugaskan kepada Pemerintah Daerah. Bidang Pengelolaan Pasar mempunyai tugas pokok melakukan kegiatan pengelolaan retribusi, keamanan dan kebersihan serta pengawasan dan pengembangan pasar. Bidang Pengelolaan Pasar sudah berusaha menjalankan tugasnya sesuai dengan prosedur yang ada dengan berusaha untuk melayani masyarakat dalam pengelolaan pasar dengan optimal. Namun yang menjadi kendala adalah kurangnya sarana dan prasarana yang ada. Seharusnya dengan adanya sarana dan prasarana yang ada Bidang Pengelolaan Pasar harus lebih mengoptimalkan terhadap pemungutan retribusi pasar dapat berjalan efisien serta dapat memberikan kepuasan kepada masyarakat sebagai pelanggan. Namun demikian, seringkali terjadi penanganan sampah perkotaan menjadi tidak efisien akibat keterbatasan Pemerintah baik dalam pembiayaan, jumlah personil maupun jumlah peralatan yang tersedia. Bidang Pengelolaan Pasar sebagai organisasi penyedia jasa pelayanan kebersihan pastinya dituntut untuk memberikan pelayanan yang maksimal dan berkualitas. Untuk itu, jumlah armada seharusnya mencukupi dalam setiap pekerjaannya. Begitu juga dengan pegawai sangat mempengaruhi dalam menciptakan pelayanan yang berkualitas. Karena pegawai adalah pelaksana kegiatan dalam memberikan pelayanan kepada masyarakat, Terpenuhinya jumlah pegawai, diharapkan semua pekerjaan dapat diselesaikan. Jumlah pegawai di Bidang Pengelolaan Pasar dibagi dalam berbagai bagian. Sumber daya manusia merupakan faktor pendorong keberhasilan dari sebuah organisasi, karena keberhasilan suatu organisasi tergantung dari kemampuan sumber daya manusia yang dimilki. Petugas Bidang Pengelolaan pasar dalam pemungutan retribusi pasar setiap melaksanakan tugas nya selalu disiplin dan bertanggung jawab atas pekerjannya. berikut tanggapan dari Bapak Sanusi sebagai Pedagang Kios di Pasar Baru Subang: “......setiap pekerjaan yang diberikan kepada setiap petugas pasti akan dikerjakan secara maksimal, karena pekerjaan selalu dikerjakan dengan penuh tanggung jawab dan disiplin" (Hasil Wawancara, Desember 2017). Keteranagan tersebut menunjukkan bahwa Petugas pemungut retribusi pasar yang dimiliki oleh Dinas Koperasi, UMKM, Perdagangan Dan Perindustrian Kabupaten Subang sudah cukup baik. Petugas selalu bekerja tanpa menghiraukan keadaan yang ada. Seperti pada petugas pemungut retribusi, petugas sudah mulai bekerja menagihi retribusi itu malam hari. Karena dengan pekerjaan dimualai jam segitu agar toko-toko dan Kios, akan tetapi Sarana yang dimiliki kurang mencukupi dan sangat mempengaruhi pegawai dalam memberikan pelayanan dan melaksanakan pekerjaan. Efisiensi merupakan kriteria efektivitas mengacu pada ukuran penggunaan sumber daya yang langka oleh organisasi. Efisiensi merupakan perbandingan antara keluaran dan masukan. Ukuran efisiensi terdiri dari keuntungan dan modal, biaya per unit, pemborosan, 
waktu terluang, biaya per orang, dan sebagainya. Efisiensi diukur berdasarkan rasio antara keuntungan dengan biaya atau waktu yang digunakan. Kemudian menurut salah satu pedagang Pasar Baru Subang menyatakan bahwa : "Memang jumlah pasar di Kabupaten Subang banyak yang kurang terawat sehingga banyaknya pasar yang hanya jumlah los dan kios nya aja yang banyak namun tidak terisi yang diakibatkan pedagang lebih memilih lokasi berdagang yang di tempat yang lama yaitu di pujasera, sehingga biaya yang dikelurkan dalam membangun jadi sia karena banyak yang kosong kios atau los ". (Hasil wawancara, Desember 2017). Dapat disimpulkan bahwa efisiensi dalam pemungutan retribusi pasar pada Dinas Koperasi, UMKM, Perdagangan dan Perindustrian Kabupaten Subang dilihat dari aspek penggunaan anggaran/dana yang dikeluarkan belum sepenuhnya efisien karena terjadi pengeluaran yang besar, sedangkan pemanfaatan dari biaya pengeluaran dari biaya penggunaan sarana/prasarana (peralatan) dan penggunaan sumber daya manusia belum menunjukkan bahwa tingkat efisiensi pemanfaatannya kurang maksimal.

\section{b.3 Kualitas}

Kinerja juga dapat dilihat dari kualitas yang diberikan organisasi publik terhadap masyarakat. Karena sekarang ini, kualitas menjadi cenderung penting dalam menjelaskan kinerja organisasi pelayanan publik. Banyak terjadi kasus ketidak puasan terhadap kualitas layanan dari suatu organisasi publik. Maka dari itu, kepuasan masyarakat terhadap layanan yang didapat, dapat dijadikan indikator kinerja organisasi publik. Penggunaan kepuasan masyarakat menjadi keuntungan karena informasi tentang kepuasan masyarakat seringkali tersedia secara mudah dan murah. Menurut Tjiptono (2002 : 53) "Kualitas adalah segala sesuatu yang memuaskan pelanggan atau sesuai dengan persyaratan atau kebutuhan". Oleh karena itu, kualitas dapat diberi pengertian sebagai totalitas dari karakteristik suatu produk (barang atau jasa) yang menunjang dalam kemampuan memenuhi kebutuhan (Kurniawan (2005 : 53-54). Seperti yang telah dijelaskan, bahwa kinerja oganisasi publik juga dapat dilihat dari kualitas pelayanan yang diberikan organisasi publik tersebut kepada masyarakat. Kualitas pelayanan yang diberikan Dinas Koperasi, UMKM, Perdagangan dan Perindustrian Kabupaten Subang adalah bagaimana mengukur derajat kesesuaian antara kualitas produk atau jasa yang dihasilkan dengan kebutuhan dan harapan masyarakat dalam hal pemungutan retribusi pasar. Ketersediaan sarana dan prasarana yang baik, akan mempengaruhi persepsi masyarakat terhadap kualitas pelayanan. Sarana dan prasarana tersebut sebagai contoh seperti pasar yang tertata dengan rapi, tersedianya akses kendaraan angkutan umum. Berikut penuturan kepala Seksie retribusi. "Pelayanan terhadap kebutuhan masyarakat masih belum maksimal karena kurang tersedianya sarana dan prasaran serta belum optimalnya biaya operasional yang di miliki oleh Dinas Koperasi, UMKM, Perdagangan dan Perindustrian Kabupaten Subang. Sehingga pelayanan kepada masyarkat menjadi kurang". (Hasil Wawancara, Desember 2017 ). 
Berdasarkan hasil wawancara diatas, salah satu bentuk kualitas adalah mengenai sarana dan prasarana yang ada di Dinas Koperasi, UMKM, Perdagangan dan Perindustrian Kabupaten Subang menyangkut pada pemberian pelayanan kepada masyarakat. Sebagai penyedia pelayanan, harus selalu memperhatikan sarana dan prasarana untuk suatu kegiatan pelayanan kepada masyarakat dalam pemungutan retribusi pasar. Karena bagaimana pelayanan terhadap kebersihan akan optimal kalau sarana dan prasarana masih menjadi permasalahan. Berdasarkan Data diatas dapat disimpulkan bahwa Dinas Koperasi, UMKM, Perdagangan dan Perindustrian Kabupaten Subang sudah berusaha untuk melayani masyarakat dalam pemungutan retribusi pasar dengan optimal. Namun yang menjadi kendala adalah kurangnya sarana dan prasarana yang ada. Seharusnya dengan adanya sarana dan prasarana yang ada Dinas Koperasi, UMKM, Perdagangan dan Perindustrian Kabupaten Subang harus lebih mengoptimalkan terhadap pengelolaan pasar dapat berjalan efektif dan efisien serta dapat memberikan kepuasan kepada masyarakat sebagai pelanggan. Namun demikian, seringkali terjadi penanganan sampah perkotaan menjadi tidak efektif akibat keterbatasan Pemerintah baik dalam pembiayaan, jumlah personil maupun jumlah peralatan yang tersedia. Sebagai organisasi penyedia jasa pelayanan kebersihan pastinya dituntut untuk memberikan pelayanan yang maksimal dan berkualitas. Untuk itu, jumlah armada seharusnya mencukupi dalam setiap pekerjaannya. Begitu juga dengan pegawai sangat mempengaruhi dalam menciptakan pelayanan yang berkualitas. Karena pegawai adalah pelaksana kegiatan dalam memberikan pelayanan kepada masyarakat, Terpenuhinya jumlah pegawai, diharapkan semua pekerjaan dapat diselesaikan. Jumlah pegawai di Dinas Koperasi, UMKM, Perdagangan dan Perindustrian Kabupaten Subang dibagi dalam berbagai bagian. Dapat disimpulkan bahwa Kualitas Layanan merupakan hal yang penting dalam kinerja Bidang Pengelolaan Pasar dalam pemungutan retribusi pasar pada Dinas Koperasi, UMKM, Perdagangan dan Perindustrian Kabupaten Subang. Karena baik atau buruknya pelayanan pengelolaan retribusi pasar tergantung bagaimana kualitas layanan yang diberikan Dinas Koperasi, UMKM, Perdagangan dan Perindustrian Kabupaten Subang kepada masyarakat. Kualitas Layanan yang diberikan oleh Dinas Koperasi, UMKM, Perdagangan dan Perindustrian Kabupaten Subang Sudah Cukup baik walaupun belum maksimal dan perlu ditingkatkan lagi kualitas layanan. Namun kendala yang dimilki adalah kurangnya sarana dan prasarana yang dimiliki sehingga kinerja Dinas Koperasi, UMKM, Perdagangan dan Perindustrian Kabupaten Subang dalam pengelolaan pasar menjadi terganggu.

\section{b.4 Ketepatan Waktu}

Ketepatan Waktu mengukur apakah pekerjaan apakah diselesaikan secara benar dan tepat waktu. Untuk itu, perlu ditentukan kriteria yang dapat mengukur berapa lama waktu yang seharusnya diperlukan untuk menghasilkan suatu produk. kriteria ini biasanya didasarkan pada harapan konsumen. Kinerja Bidang 
Pengelolaan Pasar Dalam Pemungutan Retribusi Pasar pada Dinas Koperasi, UMKM, Perdagangan Dan Perindustrian Kabupaten Subang agar ketepatan waktu dalam pelayanan harus mengenali kebutuhan masyarakat, menyusun agenda dan prioritas pelayanan dan mengembangkan program-program pelayanan publik sesuai dengan kebutuhan dan aspirasi masyarakat. ketepatan waktu menunjukan pada keselarasan antara program dan kegiatan pelayanan dengan kebutuhan dan aspirasi masyarakat. Ketepatan waktu merupakan kemampuan organisasi untuk mengidentifikasi kebutuhan masyarakat, menyusun prioritas kebutuhan dan mengembangkannya ke dalam berbagai program pelayanan. Ketepatan waktu dimasukkan sebagai salah satu indikator kinerja karena secara langsung menggambarkan kemampuan organisasi publik dalam menjalankan misi dan tujuannya, terutama untuk memenuhi kebutuhan masyarakat. Kinerja Bidang Pengelolaan Pasar Dalam Pemungutan Retribusi Pasar pada Dinas Koperasi, UMKM, Perdagangan Dan Perindustrian Kabupaten Subang adalah salah satu organisasi pelayanan publik yang selalu berusaha memberikan pelayanan terbaik berupa pelayanan prima agar dapat memenuhi kebutuhan dan harapan masyarakat. Untuk itu dituntut Kinerja Bidang Pengelolaan Pasar Dalam Pemungutan Retribusi Pasar pada Dinas Koperasi, UMKM, Perdagangan Dan Perindustrian Kabupaten Subang harus selalu tanggap terhadap kebutuhan masyarakat serta terhadap keluhan-keluhan yang disampaikan masyarakat. Disinilah pegawai harus tanggap dalam mengahadapi pedagang dan dapat menyelesaikan keluhan-keluhan yang disampaikan pedagang dengan demikian menjadi lebih mengerti tentang bagaimana retribusi dijadikan perbaiakan untuk meningkatkan pelayanan pasar yang baik. Dalam pengelolaan pasar bukan hanya dari pegawai pengelolaan pasar saja yang harus bertanggung jawab tetapi peran serta stakeholder sangat penting dibutuhkan dalam meningkatkan pelayanan pasar. Dengan responnya mantri pasar sebagai pemungut retribusi pasar maka diharapkan akan mengurangi keluhan pedagang dan pedagang maupun pembeli dapat merasakan kenyamanan dalam berbelanja. Berdasarkan hasil wawancara diatas bahwa ketepatan waktu pegawai dalam pengelolaan retribusi pasar masih banya keluhan yang disampaikan oleh masyarakat.

Dapat disimpulkan bahwa ketepatan waktu petugas kebersihan pada Dinas Koperasi, UMKM, Perdagangan Dan Perindustrian Kabupaten Subang dalam Pengelolaan pasar dapat dikatakan sudah baik walaupun belum maksimal dan masih perlu ditingkatkan. dalam pengelolaan pasar Dinas Koperasi, UMKM, Perdagangan Dan Perindustrian Kabupaten Subang tentu saja harus tetap meningkatkan upaya-upaya agar masyarakat puas dengan pelayanan yang diberikan. masih sering terjadi keterlambatan dalam penumpulan retribusi pasr dan tidak sesuai jadwal yang ditetapkan sehingga Dinas Koperasi, UMKM, Perdagangan Dan Perindustrian Kabupaten Subang harus tetap harus lebih maksimal dalam menanggapi keluhan masyarakat. 


\section{b.5 Produktivitas}

Produktivitas pada umumnya dipahami sebagai rasio antara input dan output yang dapat diartikan sejauh mana perbandingan antara upaya yang dilakukan dengan hasil yang diperoleh. Produktivitas secara konseptual adalah hubungan antara keluaran atau hasil organisasi dengan masukan yang diperlukan. Menaikan produktivitas dapat dilakukan dengan memperbaiki rasio produktivitas, dengan menghasilkan lebih banyak keluaran atau output yang lebih baik dengan tingkat masukan sumber daya tertentu. Suatu organisasi dikatakan produktif apabila mencapai tujuannya dan hal itu terjadi dengan mengubah masukan menjadi keluaran dengan biaya rendah. Dalam penelitian ini produktivitas di Bidang Pengelolaan Pasar Dinas Koperasi, UMKM, Perdagangan Dan Perindustrian Kabupaten Subang meliputi pelayanan yang dikeluarkan oleh Dinas Koperasi, UMKM, Perdagangan Dan Perindustrian Kabupaten Subang memiliki hasil yang diharapkan sebagai salah satu indikator kinerja yang penting. Dalam menjalankan tugasnya Dinas Koperasi, UMKM, Perdagangan Dan Perindustrian Kabupaten Subang mempunyai tujuan sebagai berikut sebagai Penyelenggara dan pengendali kegiatan teknis operasional pengelolaan retribusi pasar. Seperti yang dikatakan oleh Kepala Bidang Pengelolaan Pasar sebagai berikut : “.....Tujuannya yang pertama, Dinas Koperasi, UMKM, Perdagangan Dan Perindustrian Kabupaten Subang sebagai unsur pelaksana Pemerintah Daerah di Bidang Pengelolaan Pasar. Kita ingin melayani masyarakat secara baik, berkualitas dan disini dari awal kita sudah berkomitmen, pelayanan yang diberikan kepada masyarakat Bidang Pengelolaan Pasar harus menyelesaikan tugas dengan baik" (hasil wawancara, Desember 2017). Dari hasil penuturan Kepala Bidang Pengelolaan Pasar dapat disimpulkan bahwa Dinas Koperasi, UMKM, Perdagangan Dan Perindustrian Kabupaten Subang mempunyai tujuan untuk melayani masyarakat dengan baik dan berkualitas. Pelayanan yang diberikan oleh juga cepat, sehingga menjadikan lebih bersih dengan adanya pelayanan yang berkualitas pembeli pun akan dapat berbelanjan ke Pasar Tradisional, maka banyak masyarakat merasa puas dengan pelayanan yang diberikan. Pelayanan pengelolaan pasar yang diberikan oleh Dinas Koperasi, UMKM, Perdagangan Dan Perindustrian Kabupaten Subang termasuk dalam pelayanan publik yang bertujuan untuk melayani masyarakat dalam pengelolaan retribusi pasar yang dihasilkan. Dalam pelayanan pengelolaan pasar sangat dibutuhkan kinerja atau performance yang baik sehingga pemungutan retribusi dapat berjalan efektif dan efisien serta dapat memberikan kepuasan kepada masyarakat sebagai pelanggan. Namun demikian, seringkali terjadi pelayanan retribusi pasar menjadi tidak efektif akibat keterbatasan Pemerintah baik dalam pembiayaan, jumlah personil maupun jumlah peralatan yang tersedia. Permasalahan yang terjadi di Kabupaten Subang tidak tercapinya target retribusi pasar. Dapat disimpulkan bahwa produktivitas Dinas Koperasi, UMKM, Perdagangan Dan Perindustrian Kabupaten Subang sudah baik walaupun belum maksimal dan perlu ditingkatkan. Dilihat dari sistem pemungutan retribusi pasar rutin di lakukan walaupun masih 
adanya pedagang yeang mebandel dengan tidak mau dalam memberikan retribusai pasar.. Maka produktivitas Dinas Koperasi, UMKM, Perdagangan Dan Perindustrian Kabupaten Subang perlu di tingkatkan lagi dalam meberikan Pelayanan pengelolaan pasar terhadap masyarakat.

\section{Kesimpulan}

Berdasarkan hasil analisis dan pembahasan yang dilakukan, dapat ditarik beberapa kesimpulan mengenai Kinerja Bidang Pengelolaan Pasar Dalam Pemungutan Retribusi Pasar pada Dinas Koperasi, UMKM, Perdagangan Dan Perindustrian Kabupaten Subang, sebagai berikut :

a) Kinerja Bidang Pengelolaan Pasar Dalam Pemungutan Retribusi Pasar pada Dinas Koperasi, UMKM, Perdagangan Dan Perindustrian Kabupaten Subang secara umum belum optimal. Hal ini dapat dilihat dari kinerja pegawai dalam pemungutan retribusi pasar yang tidak efektif, Produktivitas pemungutan retribusi pasar yang masih kurang optimal. Berdasarkan kelima dimensi dalam pengukuran kinerja organisasi menurut Moeheriono, yaitu efektivitas, efisiensi, kualitas, ketepatan waktu dan produktivitas dapat ditarik kesimpulan sebagai berikut :

b) Dimensi Efektivitas, Dapat disimpulkan bahwa Kinerja Bidang Pengelolaan Pasar Dalam Pemungutan Retribusi Pasar pada Dinas Koperasi, UMKM, Perdagangan Dan Perindustrian Kabupaten Subang dapat dikatakan sudah baik walaupun belum maksimal dan masih perlu ditingkatkan. Kinerja Bidang Pengelolaan Pasar Dalam Pemungutan Retribusi Pasar pada Dinas Koperasi, UMKM, Perdagangan Dan Perindustrian Kabupaten Subang tentu saja harus melakukan sesuatu dengan benar sesuai derajat kesesuaian output yang dihasilkan dalam mencapai sesuatu yang diinginnkan, sehingga masyarakat masyarakat puas dengan pelayanan yang diberikan.

c) Dimensi Efisiensi, Dapat disimpulkan bahwa efisiensi dalam pemungutan retribusi pasar Kinerja Bidang Pengelolaan Pasar pada Dinas Koperasi, UMKM, Perdagangan Dan Perindustrian Kabupaten Subang dilihat dari aspek penggunaan anggaran/dana yang dikeluarkan belum sepenuhnya efisien karena terjadi pengeluaran yang besar, sedangkan pemanfaatan dari biaya pengeluaran dari biaya penggunaan sarana/prasarana (peralatan) dan penggunaan sumber daya manusia belum menunjukkan bahwa tingkat efisiensi pemanfaatannya karena masih banyak peralatan seperti banyak nya los/kios yang dalam keadaan rusak sedang sampai ringan dan tidak adanya pedagang.

d) Dimensi Kualitas, dalam pemungutan retribusi pasar Kualitas Layanan yang diberikan oleh Kinerja Bidang Pengelolaan Pasar pada Dinas Koperasi, UMKM, Perdagangan Dan Perindustrian Kabupaten Subang Sudah Cukup baik walaupun belum maksimal dan perlu ditingkatkan lagi kualitas layanan. Namun kendala yang dimilki adalah kurangnya sarana dan prasarana yang dimiliki sehingga k Kinerja 
Bidang Pengelolaan Pasar Dalam Pemungutan Retribusi Pasar pada Dinas Koperasi, UMKM, Perdagangan Dan Perindustrian Kabupaten Subang menjadi terganggu.

e) Dimensi Ketepatan Waktu, Dapat disimpulkan bahwa ketepatan waktu Kinerja petugas Bidang Pengelolaan Pasar Dalam Pemungutan Retribusi Pasar pada Dinas Koperasi, UMKM, Perdagangan Dan Perindustrian Kabupaten Subang dapat dikatakan sudah baik walaupun belum maksimal dan masih perlu ditingkatkan. Dalam pemungutan retribusi pasar Bidang Pengelolaan Pasar pada Dinas Koperasi, UMKM, Perdagangan Dan Perindustrian Kabupaten Subang tentu saja harus tetap meningkatkan upaya-upaya agar masyarakat puas dengan pelayanan yang diberikan.

f) Dimensi Produktivitas, Dapat disimpulkan bahwa produktivitas Kinerja Bidang Pengelolaan Pasar Dalam Pemungutan Retribusi Pasar pada Dinas Koperasi, UMKM, Perdagangan Dan Perindustrian Kabupaten Subang masih belum maksimal dan perlu ditingkatkan. Dilihat dari tidak tercapainya target pemungutan retribusi pasar dikarenakan petugas yang kurang optimal dalam pemungtan retribusi kepada pedagang.

\section{Referensi}

Abdul Syani. 2012. Sosiologi Skematika, Teori dan Terapan. Bumi Aksara : Yogyakarta Atmosudirjo, Prajudi. 1995. Kesekertariatan dan Administrasi Perkantoran. Galian Indonesia : Jakarta

Creswell, Jhon. 2010. Research Design Pendekatan Kualitatif, Kuantitatif dan Mixed. Pustaka Pelajar : Yogyakarta

Dwiyanto, Agus. 2006. Reformasi Birokrasi Publik di Indonesia. Gajah Mada University press :Yogyakarta

Hetifah Sj, Sumarto. 2009. Partisipasi, Inovasi dan Good Governance. Salembe Empat: Jakarta

Mahmudi. 2005. Manajemen Kinerja Sektor Publik. UPP. AMP YKPN : Yogyakarta

Mahsun, Muhamad. 2009. Pengukuran Kinerja Sektor Publik. BPFE : Yogyakarta

Mangkunegara. 2010. Evaluasi Kinerja SDM. PT. Refika Aditama : Bandung

Mejia, Dkk. 2007. Managing Human Resource Edition. Pearson Education : New Jersey

Moeheriono. 2010. Pengukuran Kinerja Berbasis Kompetensi. Ghalia Indonesia: Bogor

Monday, and Noe. 1993. Human Resource Management. A Division At Simon and Schuster, Inc : USA

Pasolong, Harbani. 2008. Teori Administrasi Publik. Alfabeta : Bandung

Ratminto dan Winarsih, 2004. Manajemen Pelayanan, Pustaka Pelajar:Yogyakarta 
Sedarmayanti, Sumber Daya Manusia dan Produktivitas Kerja, Penerbit CV. Mandar Maju: Bandung

Siagian, Sondang. 2002. Manajemen Sumber Daya Manusia. PT. Bumi Aksara: Jakarta

Sobandi, Baban. 2006. Desentralisasi dan Tututan Penataan Kelembagaan Daerah. Humaniora : Bandung

Sutarto. 2006. Dasar-Dasar Organisasi. Gajah Media University Press : Yogyakarta

Sugiyono.2011. Metode Penelitian Administrasi Kualitatif dan Kuantitatif RED.ALFABETA : Bandung 